\title{
sciendo
}

\section{DETECTION OF SINGLE NUCLEOTIDE POLYMORPHISMS AT MAJOR PROLIFICACY GENES IN THE MEHRABAN SHEEP AND ASSOCIATION WITH LITTER SIZE*}

\author{
Reza Talebi ${ }^{1}$, Ahmad Ahmadi ${ }^{1 \star}$, Fazlollah Afraz ${ }^{2}$, Julien Sarry ${ }^{3}$, Florent Woloszyn ${ }^{3}$, Stéphane Fabre \\ ${ }^{1}$ Department of Animal Sciences, Faculty of Agriculture, Bu-Ali Sina University, Hamedan, Iran \\ ${ }^{2}$ Department of Livestock and Aquaculture Biotechnology, \\ Agricultural Biotechnology Research Institute of North Region, Rasht, Iran \\ ${ }^{3}$ GenPhySE, Université de Toulouse, INRA, ENVT, Castanet Tolosan, France \\ •Corresponding author: ahmadi@basu.ac.ir
}

\begin{abstract}
The present study aimed to investigate the presence of polymorphisms at four known genes controlling ovine prolificacy i.e. BMP15, GDF9, BMPR1B and B4GALNT2 in a sample of 115 Iranian Mehraban ewes and their association with litter size (LS) and lambs' birth weight (BW) traits. Using Sanger sequencing of exons and polymorphism specific genotyping, ten SNPs (Single Nucleotide Polymorphisms) were observed in only two genes, GDF9 and BMPR1B. Seven SNPs were found in the $G D F 9$ gene on the chromosome 5. Among them, six were already described in the coding sequence, and a new one (g.41840985C $>$ T) was found in the 3'UTR. In the BMPR1B gene on the chromosome 6, three novel SNPs were detected in the exon 7 (g.29382184G $>A$; g.29382337G $>A$

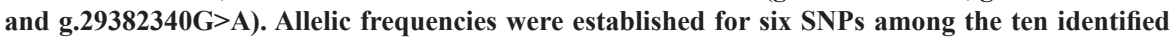
and they were in Hardy-Weinberg equilibrium. A significant association was found between the novel SNPs found in the exon 7 of $B M P R 1 B$ and LS. Present results indicate the potential role of the $B M P R 1 B$ locus in controlling prolificacy of Mehraban sheep and provide genetic markers for further exploitation in selection to improve reproductive efficiency.
\end{abstract}

Key words: polymorphism, Mehraban sheep, major genes, prolificacy

There are more than 50 million heads of sheep in Iran, including 27 breeds and ecotypes (retrieved from Zamani and Mohammadi, 2008). Among them, the Mehraban sheep originates from the Hamadan western province of Iran and is a dual-purpose breed used for both wool and meat production. The breed counts approximately 2.2 million heads (Atashi et al., 2013). The Mehraban sheep exhibits a high genetic variability, opening interesting prospects for future selection programs and preservation strategies (Bahrami et al., 2013). The breed has a higher litter size (LS), fertility and survival rate from birth to weaning when compared to other Iranian native sheep

\footnotetext{
*This work was supported by "Bu-Ali Sina University" of Hamedan, Iran and GenPhySE laboratory of French National Institute for Agricultural Research (INRA), Costanet Tolosan, France.
} 
(Zamani and Mohammadi, 2008). An interesting lever to improve sheep productivity is the increased number of lambs produced per ewe. Indeed, LS is economically the most important trait in lamb meat production and higher LS also allows more selection pressure on the other economically important traits. Because the heritability of LS is usually low, selection on phenotype is expected less effective in improving LS (reviewed in Janssens et al., 2004). Therefore, inclusion of genetic information of the genes associated with reproductive ability could efficiently enhance the response (retrieved from Abdoli et al., 2016).

Since the 1980s, extensive research has been conducted to decipher the inheritance patterns of sheep prolificacy. This research has demonstrated that LS and the associated ovulation rate (OR) can be genetically regulated either by a set of different genes, each having a small effect (Ricordeau et al., 1990) and/or by major genes having large effect and the potential to significantly increase the sheep reproductive efficiency (reviewed in Davis, 2005; Drouilhet et al., 2009). Up to now, four major genes affecting prolificacy ( $F e c$ genes) namely $B M P R 1 B / F e c B$ (bone morphogenetic protein receptor type 1B), BMP15/FecX (bone morphogenetic protein 15), GDF9/ $F e c G$ (growth and differentiation factor 9) and B4GALNT2/FecL (beta-1,4-N-acetylgalactosaminyl transferase 2), have been evidenced and genetically described in different sheep breeds (Galloway et al., 2000; Mulsant et al., 2001; Wilson et al., 2001; Hanrahan et al., 2004; Nicol et al., 2009; Drouilhet et al., 2013). Other Fec genes are also known to exist from the expressed inheritance patterns, although the mutations have not yet been identified (Davis, 2005). Among the identified Fec genes, numerous causative mutations have been discovered in various sheep populations worldwide. BMPR $1 B$ and $B 4 G A L N T 2$ carry only one prolific allele, $F e c B^{B}$ and $F e c L^{L}$, respectively (Mulsant et al., 2001; Drouilhet et al., 2013). In contrast, BMP15 and GDF9 accumulate numerous prolific alleles such as $F e c X^{I}, F e c X^{H}, F e c X^{B}, F e c X^{G}$, $F e c L^{L}, F e c X^{R}, F e c X^{G r}, F e c X^{O}$ for $B M P 15$ and Fec $G^{H}, F e c G^{T}, F e c G^{E}, F e c G^{N W S}, F e c G^{V}$ for GDF9 (for an overall report of prolific alleles in ovine BMP15 and GDF9 genes, see Persani et al., 2014). The additive effect of a single copy of the prolific alleles ranges from 0.4 to 1.5 extra ovulations per oestrus cycle and 0.25 to 1.0 more lamb per lambing and ewe (Davis, 2005).

With the discovery of these numerous prolific alleles, the study of fecundity genes has become of great importance in sheep production, because it provides important genetic tools for improving reproductive efficiency (Notter, 2008; Nicol et al., 2009). Given the potential economic impact of lambing rate, the objective of this study was to investigate in Mehraban sheep the existence of polymorphisms in four fecundity genes i.e. BMP15, GDF9, BMPR1B and B4GALNT2. Current results are expected to provide genetic markers potentially associated with prolificacy in Mehraban sheep and assist in designing a breeding program of this trait in the future.

\section{Material and methods}

\section{Animals and blood sampling}

One hundred and fifteen Mehraban ewes (115) were randomly chosen for the current analysis from the research farm of Bu-Ali Sina University in Dastjerd region, 
located in Hamedan province in western Iran. Records on litter size (from 1 to 5 LS record/ewe) and lambs' birth weight (BW) were collected between years 2008 and 2016 accompanied with information of lambing season (February-March). For some analyses, among the 115 ewes we have formed two groups of extreme prolificacy, the highly prolific group ( $\mathrm{n}=8 ; \mathrm{LS} \geq 2 ; 2 \mathrm{SD}$ away from the mean LS) and the lowly prolific group $(\mathrm{n}=8 ; \mathrm{LS}=1)$. Blood samples ( $5 \mathrm{ml}$ per animal) were taken from the jugular vein by Venoject tubes containing EDTA. Genomic DNA (gDNA) was extracted from whole blood using a salting out DNA extraction method (Montgomery and Sise, 1990) and kept at $-20^{\circ} \mathrm{C}$. Quantity and purity assessment of gDNA were determined using NanoDrop ${ }^{\circledR}$ ND-8000 based on absorbance at 260 and $280 \mathrm{~nm}$ (A260/A280).

\section{PCR amplification}

Primers used for the PCR amplification are indicated in Table 1. The PCR reaction was carried out in $20 \mu \mathrm{l}$ final volume consisting of $1 \mathrm{X}$ PCR buffer $(50 \mathrm{mMKCl}$, 10 mMTris-HCl, $\mathrm{pH} 8.0)$, primers $(0.25 \mu \mathrm{M}$ each), dNTPs $(200 \mu \mathrm{M}), 0.5$ units of GoTaq polymerase (Promega, Charbonnières-les-Bains, France) and gDNA (50 ng). The PCR running condition was as follows: initial denaturation at $94^{\circ} \mathrm{C}$ for 5 minutes followed by 35 cycles of amplification $\left(94^{\circ} \mathrm{C} / 30 \mathrm{sec}, 55-58^{\circ} \mathrm{C} / 30 \mathrm{sec}, 72^{\circ} \mathrm{C} / 30 \mathrm{sec}\right)$ and final extension at $72^{\circ} \mathrm{C}$ for 7 minutes.

Table 1. PCR primer sequences

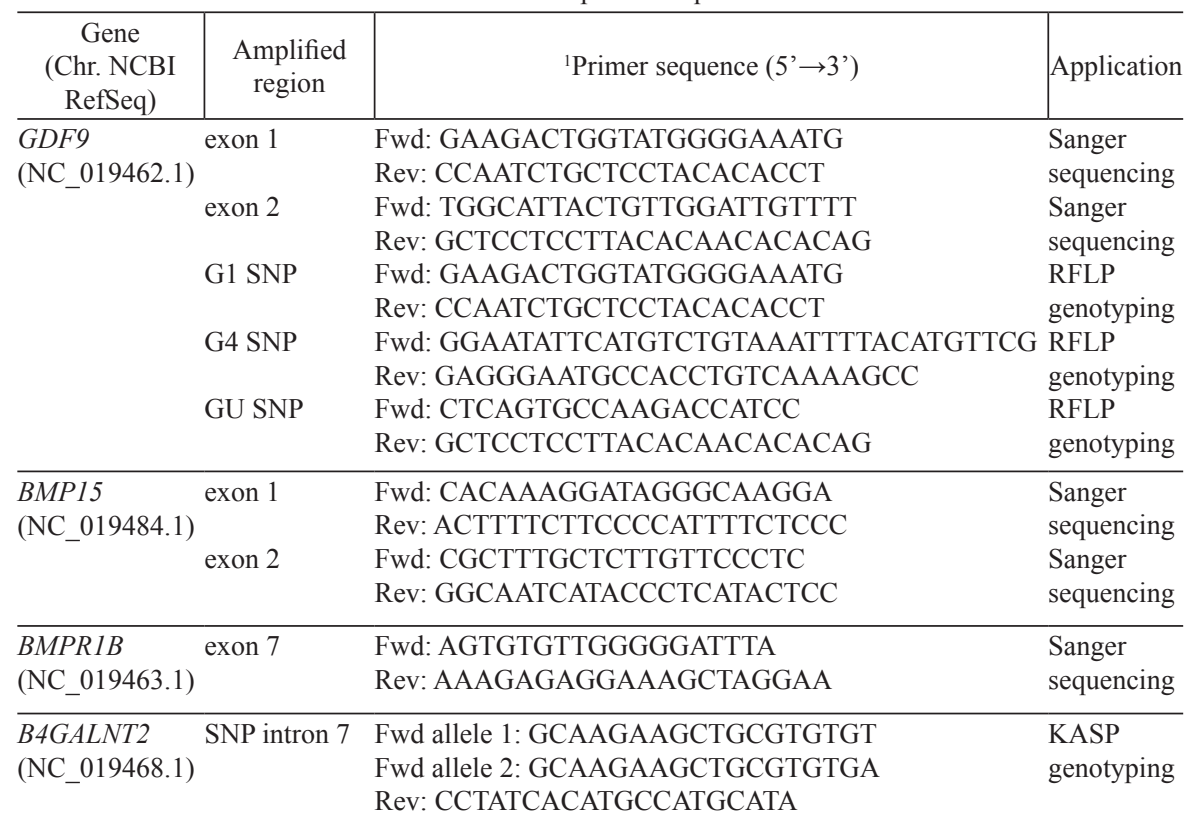

${ }^{1}$ Fwd and Rev : Forward and Reverse primers. 


\section{DNA sequencing}

Before sequencing, PCR products were purified from amplification primers by Alkaline Phosphatase (TSAP 1U/ $\mu$, Promega) and Exonuclease I (Exo1 20U/ $\mu \mathrm{l}$, Ozyme, Montigny-le-Bretonneux, France) digestion at $37^{\circ} \mathrm{C}$ for 45 minutes in a $15 \mu \mathrm{l}$ final volume. The reaction was stopped at $80^{\circ} \mathrm{C}$ for 30 minutes. The Sanger sequencing reaction was carried out in a $20 \mu \mathrm{l}$ final volume via the BigDye Terminator v3.1 Cycle Sequencing Kit and analyzed on an ABI3730 sequencing machine (Applied Biosystems) using $1 \mu \mathrm{l}$ of a $10 \mu \mathrm{M}$ specific sequencing primer (see Table 1). Once sequenced reads were obtained, they were aligned against the ovine reference sequence for each gene of interest (ovine reference genome v3.1; BMP15: NC_019484.1; GDF9: NC_019462.1 and BMPR1B: NC_019463.1) using CLC Main Workbench Version 7.6.4 (www.clcbio.com) in order to assess for polymorphisms.

\section{Polymorphism genotyping assays}

The genotyping assays of SNP G1 and G4 were already established (Hanrahan et al., 2004). G1 (OAR5:41843258G $>$ A, NC_019462.1) was tested by restriction fragment length polymorphism (RFLP) by its ability to disrupt a Hha I (5'-GCG/C) site, and G4 (OAR5:41841675A $>$ G) was assessed by forced-RFLP with mutated strand cleaved by BstB I (5'-TT/CGAA). A RFLP assay was designed for the GU SNP (OAR5:41840985C>T) with a ApeK I (5'-G/CwGC) digestion (Webcutter 2.0; http://rna.lundberg.gu.se/cutter2/). Primers used for the PCR amplification before the restriction assays are presented in Table 1. RFLP assays were resolved by a $2 \%$ agarose gel electrophoresis.

DNA sequencing of the entire $B M P R 1 B$ exon 7 was used to genotype the Booroola $F_{e c B}{ }^{B}$ (OAR6:29382188A>G, NC_019463.1) polymorphism (Mulsant et al., 2001). For B4GALNT2 (Drouilhet et al., 2013), the genotyping of FecL $L^{L}$ (B4GALNT2 intron 7, OAR11:36938224T>A, NC_019468.1) was done by fluorescent competitive allele specific PCR (KASP primers are shown in Table 1) via the KASP V4.0 2x Master mix (LGC, Molsheim, France). The KASP genotyping was analyzed by a final point read of the fluorescence on an ABI 7900HT Real-Time PCR System and using the SDS Software 2.4 (Applied Biosystems).

\section{Statistical analysis}

SNP allele proportions were tested for Hardy-Weinberg equilibrium (HWE) using the POPGENE software (Version 1.32; Yeh et al., 1999). This program was also used to estimate the pairwise linkage disequilibrium (LD) levels between SNPs based on the multi-allelic $r^{2}$ (correlation coefficient) measure, as well as to estimate dominant haplotypes for all SNPs identified in different gene loci. The following models were used to detect possible associations between the two traits and genotypes: LS: $Y_{i j g l}=$ $\mu+y e a r_{i}+N L+G_{g}+e_{i j g l}$; and BW: $Y_{i j k l m n}=\mu+y e a r_{i}+L_{j}+S e x_{k}+L S_{l}+\mathrm{G}_{m}+e_{i j k l m n}$. In these models, $Y_{i j g l}^{g}$ or $Y_{i j k l m n}$ are the phenotypic values of the studied traits; $\mu$ is the overall mean; year ${ }_{i}$ is the effect of $i$ th year of ewe lambing; $L_{j}$ is the fixed effect of lambing number $\left(j=1,2,3\right.$ and 4); $N L_{j}$ is number of lambing; $G_{g}$ is the effect of $g$ th genotype; $S e x_{k}$ is the effect of $k$ th sex of lamb; $L S_{l}$ is the effect of $l$ th litter size; $e_{i j g l}$ or $e_{i j k m n}$ are the residual effects. Association analysis was carried out using the GLM procedure of SAS software (SAS Institute, 2004). 


\section{Results}

\section{Sequencing of GDF9, BMP15 in highly and lowly prolific animals}

Of the 115 ewes, 42 ewes had only one LS record, 45 had 2 LS records and 28 had more than 3 (up to 5) LS records. The mean \pm SD of LS of this population was $1.19 \pm 0.42$, respectively. We first selected sixteen extreme prolific ewes with $\mathrm{LS} \geq$ $2(\mathrm{n}=8)$ or $\mathrm{LS}=1(\mathrm{n}=8)$ for the complete sequencing of the BMP15 and GDF9 genes.

Among the eight highly prolific ewes, five exhibited repeated lambing of twins, and three had only one lambing record with triplets. No polymorphism was observed by DNA sequencing of the exon 1 and exon 2 of BMP15 in both highly and lowly prolific Mehraban ewes. In contrast, as shown in Figure 1 and Table 2, we observed the presence of already known SNPs in the GDF9 gene named $\mathrm{G} 1(\mathrm{G}>\mathrm{A})$ in exon 1, and G2 $(\mathrm{T}>\mathrm{C}), \mathrm{G} 3(\mathrm{~A}>\mathrm{G}), \mathrm{G} 4(\mathrm{~A}>\mathrm{G}), \mathrm{G} 5(\mathrm{~A}>\mathrm{G})$ and $\mathrm{G6}(\mathrm{G}>\mathrm{A})$ in exon 2, previously reported by Hanrahan et al. (2004). Additionally, as illustrated in Figure 3, we identified a novel polymorphism in the 3'UTR of GDF9 we named GU (OAR5:41840985C>T, NC_019462.1).

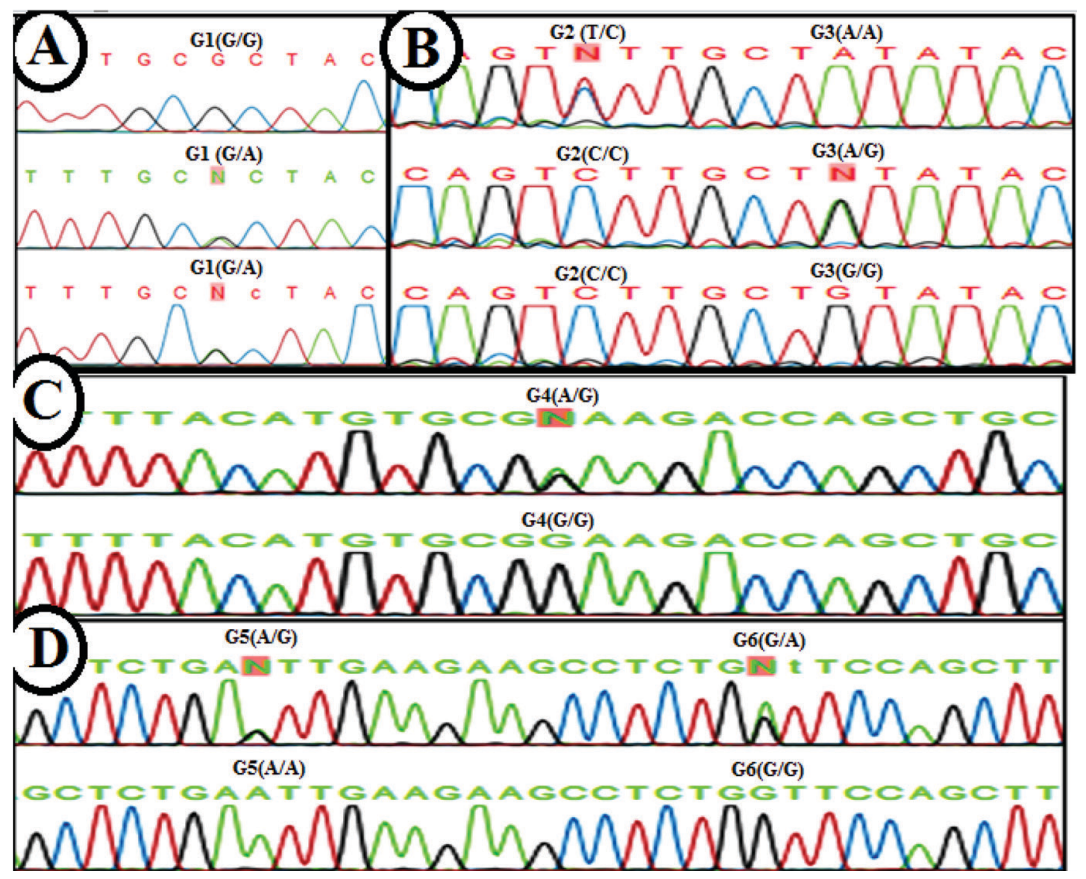

CLC Main Workbench image capture of Sanger sequencing histograms from A) FecG/GDF9 exon 1, OAR5 g.41843258G $>$ A (G1), NC_019462.1. B) FecG/GDF9 exon 2, OAR5 g.41841925 T>C (G2), and FecG/GDF9 exon 2, OAR5 g. $41841919 \mathrm{~A}>\mathrm{G}$ (G3), NC_019462.1. C) FecG/GDF9 exon 2, OAR5 g.41841675 A>G (G4), NC_019462.1. D) FecG/GDF9 exon 2, OAR5 g. 41841418 A $>$ G (G5), and FecG/GDF9 exon 2, OAR5 g. 41841402 G>A (G6), NC_019462.1. Coordinates based on Ovis aries chromosomes (OAR) reference genome v3.1.

Figure 1. Known single nucleotide polymorphisms detected in exons 1 and 2 of the GDF9 gene in Mehraban ewes 
Table 2. Identified SNPs in Mehraban sheep

\begin{tabular}{|c|c|c|c|}
\hline $\begin{array}{c}\text { Gene } \\
\text { (Chr. NCBI RefSeq) }\end{array}$ & $\begin{array}{l}\text { SNP genomic } \\
\text { location }\left(\mathrm{Chr}^{1}\right)\end{array}$ & SNP alleles & $\begin{array}{c}\text { Protein } \\
\text { position/substitution }\end{array}$ \\
\hline GDF9 (NC_019462.1) & $\begin{array}{l}5: 41843258 \\
5: 41841925 \\
5: 41841919 \\
5: 41841675 \\
5: 41841418 \\
5: 41841402 \\
5: 41840985\end{array}$ & $\begin{array}{l}\mathrm{G}>\mathrm{A}(\mathrm{G} 1) \\
\mathrm{T}>\mathrm{C}(\mathrm{G} 2) \\
\mathrm{A}>\mathrm{G}(\mathrm{G} 3) \\
\mathrm{A}>\mathrm{G}(\mathrm{G} 4) \\
\mathrm{A}>\mathrm{G}(\mathrm{G} 5) \\
\mathrm{G}>\mathrm{A}(\mathrm{G} 6) \\
\mathrm{C}>\mathrm{T}(\mathrm{GU})\end{array}$ & $\begin{array}{l}\text { p. } 87 \mathrm{R}>\mathrm{H} \\
\text { p. } 157 \mathrm{~V} \text { (unchanged) } \\
\text { p. } 159 \mathrm{~L} \text { (unchanged) } \\
\text { p. } 241 \mathrm{E}>\mathrm{K} \\
\text { p.326E (unchanged) } \\
\text { p.332V }>\mathrm{I} \\
\text { 3'UTR }\end{array}$ \\
\hline$B M P R 1 B\left(\mathrm{NC}_{-} 019463.1\right)$ & $\begin{array}{l}6: 29382340 \\
6: 29382337 \\
6: 29382184\end{array}$ & $\begin{array}{l}\mathrm{G}>\mathrm{A} \\
\mathrm{G}>\mathrm{A} \\
\mathrm{G}>\mathrm{A}\end{array}$ & $\begin{array}{l}\text { p.198R (unchanged) } \\
\text { p.199T (unchanged) } \\
\text { p.250T (unchanged) }\end{array}$ \\
\hline
\end{tabular}

${ }^{1}$ Chromosome position according to ovine reference genome v3.1.

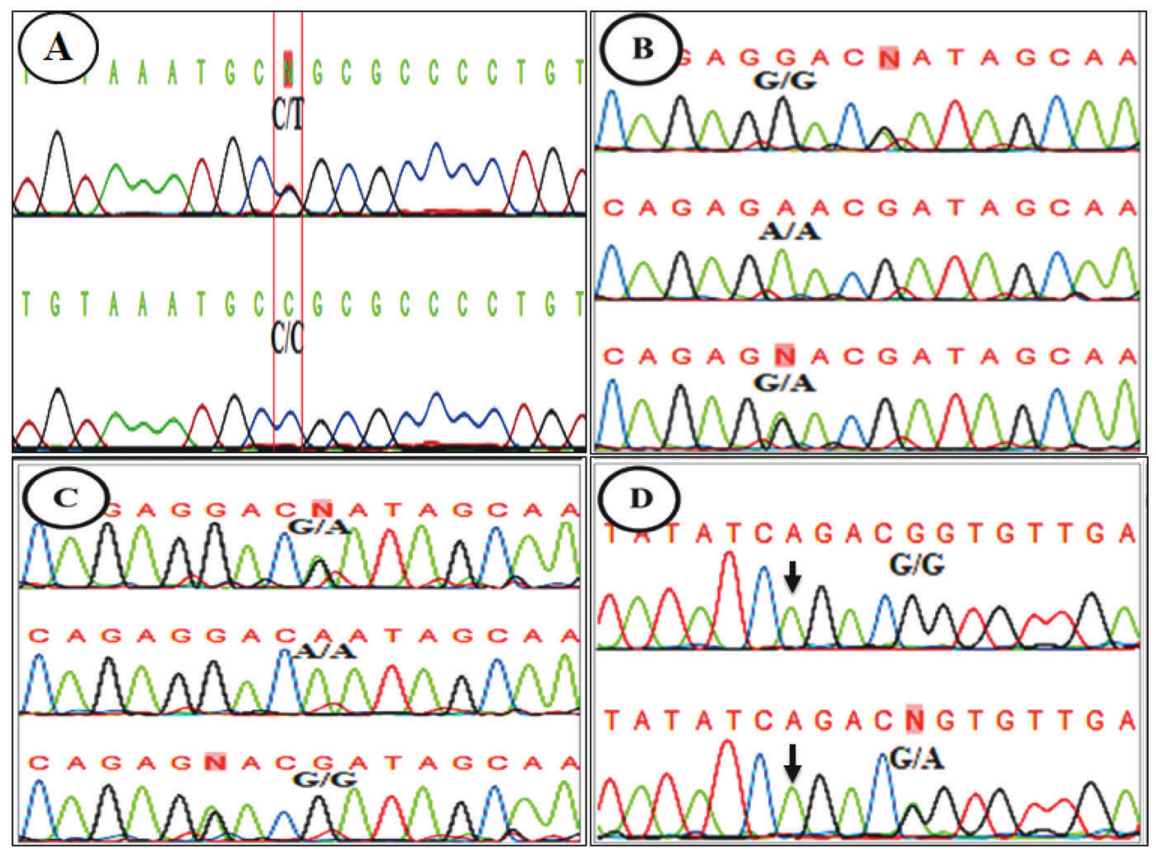

CLC Main Workbench image capture of Sanger sequencing histograms from A) FecG/GDF9 3'UTR, OAR5 g.41840985C>T, NC_019462.1. B) FecB/BMPR1B exon 7, OAR6 g.29382340G >A, NC_019463.1. C) $F e c B / B M P R 1 B$ exon 7, OAR6 g.29382337G >A, NC_019463.1. D) FecB/BMPR1B exon 7, OAR6 g.29382184G $>$ A, NC 019463.1. The black arrows indicate the position of the FecB Booroola SNP in BMPR1B exon 7. Coordinates based on Ovis aries chromosomes (OAR) reference genome v3.1

Figure 2. Novel single nucleotide polymorphisms detected at major prolificacy genes loci in Mehraban ewes 


\section{Genotyping of $G D F 9$ polymorphisms and association with litter traits}

Based on the GDF9 sequence data (Figure 1 and Figure 2), we focused on the new GU SNP, and on the G1 and G4 SNPs because they both alter the GDF9 protein sequence by non-conservative substitutions, p.Arg87His and p.Glu241Lys, respectively (Table 2). The RFLP genotyping of these three SNP was perfectly coherent with the sequencing results for the eight selected prolific ewes, indicating the good accuracy of the RFLP genotyping (Figure 3). These polymorphisms were observed in some but not all of our eight selected Mehraban prolific ewes (Figure 3). Thereafter, the entire set of the 115 Mehraban ewes with litter size records was genotyped for these three SNPs by RFLP. As illustrated in Table 3, Mehraban ewes exhibited a low frequency of the GU SNP variant allele T (0.02) with only $4 \%$ of heterozygous $\mathrm{C} / \mathrm{T}$ animals. In contrast at the G1 position, the variant allele A had a frequency of 0.15 with the presence of heterozygous G/A (27\%) and homozygous carrier animals A/A $(2 \%)$. At G4, the variant allele $G$ was the most frequent $(0.82)$ with $68 \%$ of homozygous $\mathrm{G} / \mathrm{G}$ carriers, $29 \%$ of heterozygous $\mathrm{A} / \mathrm{G}$ and $3 \%$ of homozygous non-carrier animals A/A (Table 3). Moreover, a high degree of linkage disequilibrium (LD) was estimated between G1 and G4 SNP as attested by the high correlation coefficient values $\left(r^{2}=0.91\right)$. All SNPs were in HWE. Furthermore, the three SNPs genotyped in GDF9 i.e. G1, G4 and the novel GU SNP were not found to be associated with the two traits, LS and BW (Table 4).

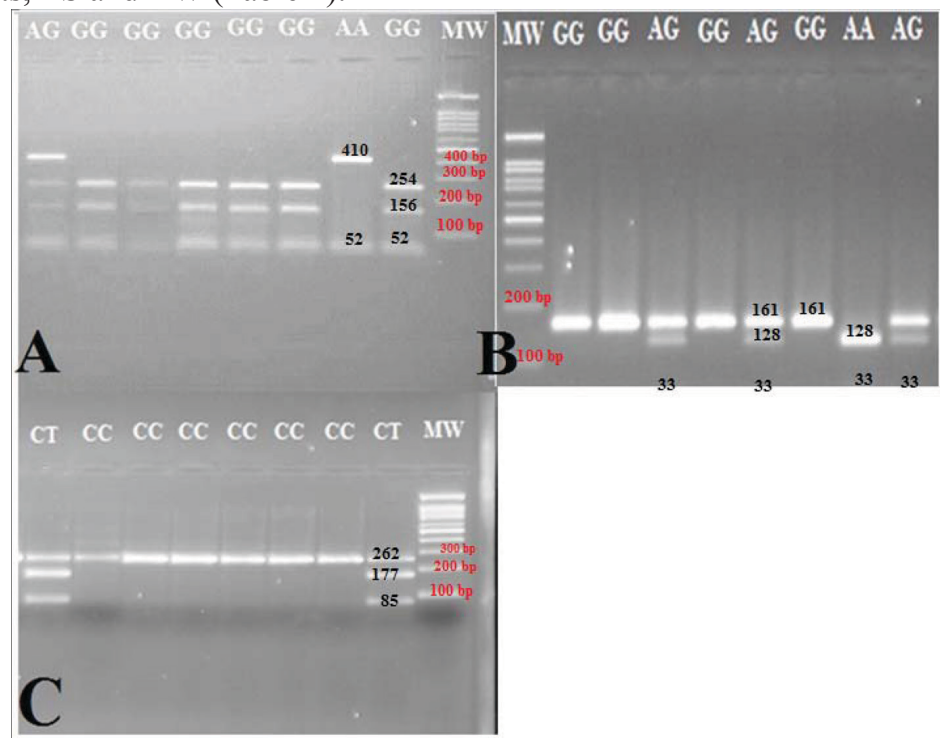

Figure 3. Agarose gel electrophoresis (2\%) of digested product of GDF9 gene through Restriction Fragment Length PolymorphismA) G1 (OAR5:41843258G>A, NC_019462.1). B) G4 (OAR5:41841675A >G, NC_019462.1). C) GU (OAR5:41840985C >T, NC_019462.1). DNA samples came from the eight most prolific Mehraban ewes. The 3 possible genotypes for G1 (homozygous non-carriers: GG, heterozygous: AG and homozygous carriers: AA), G4 (homozygous non-carriers: AA, heterozygous: AG and homozygous carriers: GG), and the two possible genotypes for the SNP in the 3' UTR of GDF9 (homozygous non-carriers: $\mathrm{CC}$ and heterozygous: $\mathrm{CT}$ ), were evidenced in accordance with sequencing results. MW: DNA molecular weight marker, informative size (bp) colored in red. The size (bp) of the digested fragments is indicated in black 
Genotyping of $B 4 G A L N T 2$ and $B M P R I B$ polymorphisms and association with litter traits

No polymorphism in BMP15 and GDF9 was found to be associated with prolificacy in the Mehraban sheep. Furthermore, the 115 Mehraban ewes were carriers of neither the Lacaune $F e c L^{L}$ prolific allele in the B4GALNT2 gene nor the Booroola $F e c B^{B}$ prolific allele in the $B M P R I B$ gene. In contrast, as illustrated in Figure 2 and Table 2, three other SNPs were detected by sequencing of the exon 7 of the BMPR1B gene, g.29382184 G>A, g.29382337 G>A and g.29382340 G>A. The allele frequencies of the three SNPs were in HWE. The polymorphism g.29382184 G>A was present in $19 \%$ of our animals only at the G/A heterozygous state (Table 3). Interestingly, the presence of the minor allele $\mathrm{A}$ was associated with a significant lower LS (1.20 vs. 1.02, G/G vs. $\mathrm{G} / \mathrm{A}, \mathrm{P}=0.02$ ) (Table 4). The two other SNPs lying in the BMPR1B exon 7, g.29382337 G>A and g.29382340 G>A, exhibited a higher frequency at the heterozygous state G/A (43 and $26 \%$, respectively) along with the presence of homozygous animals $\mathrm{A} / \mathrm{A}$ (11 and 1\%, respectively) (Table 3 ). In contrast with the previous polymorphism the minor allele A of the SNP g.29382337 G>A was found to be associated with higher LS at the homozygous state (LS: 1.41 vs. 1.12 or 1.14; A/A vs. G/A or $\mathrm{G} / \mathrm{G}, P<0.05$, Table 4). The SNP g.29382340 G $>$ A was not significantly associated with any trait (Table 4).

Table 3. Genotypic and allelic frequencies in Mehraban ewe

\begin{tabular}{|c|c|c|c|c|c|}
\hline \multirow{2}{*}{$\begin{array}{c}\text { Gene (Chr. NCBI } \\
\text { RefSeq) } \\
\text { GDF9 (NC_019462.1) }\end{array}$} & \multirow{2}{*}{\begin{tabular}{|c|} 
SNP \\
$5: 41843258 \mathrm{G}>\mathrm{A}(\mathrm{G} 1)$
\end{tabular}} & \multicolumn{2}{|c|}{ Genotype frequency } & \multicolumn{2}{|c|}{ Allele frequency } \\
\hline & & $\mathrm{G} / \mathrm{G}$ & 0.71 & G & 0.85 \\
\hline & & $\mathrm{G} / \mathrm{A}$ & 0.27 & & \\
\hline & & $\mathrm{A} / \mathrm{A}$ & 0.02 & A & 0.15 \\
\hline & $5: 41841675 \mathrm{~A}>\mathrm{G}(\mathrm{G} 4)$ & $\mathrm{A} / \mathrm{A}$ & 0.03 & A & 0.18 \\
\hline & & $\mathrm{A} / \mathrm{G}$ & 0.29 & & \\
\hline & & $\mathrm{G} / \mathrm{G}$ & 0.68 & G & 0.82 \\
\hline & 5: 41840985C $>\mathrm{T}(\mathrm{GU})$ & $\mathrm{C} / \mathrm{C}$ & 0.96 & $\mathrm{C}$ & 0.98 \\
\hline & & $\mathrm{C} / \mathrm{T}$ & 0.04 & $\mathrm{~T}$ & 0.02 \\
\hline \multirow[t]{8}{*}{ BMPRIB (NC_019463.1 } & $6: 29382340 \mathrm{G}>\mathrm{A}$ & $\mathrm{G} / \mathrm{G}$ & 0.73 & G & 0.86 \\
\hline & & $\mathrm{G} / \mathrm{A}$ & 0.26 & & \\
\hline & & $\mathrm{A} / \mathrm{A}$ & 0.01 & A & 0.14 \\
\hline & $6: 29382337 \mathrm{G}>\mathrm{A}$ & $\mathrm{G} / \mathrm{G}$ & 0.46 & G & 0.67 \\
\hline & & $\mathrm{G} / \mathrm{A}$ & 0.43 & & \\
\hline & & $\mathrm{A} / \mathrm{A}$ & 0.11 & $\mathrm{~A}$ & 0.33 \\
\hline & $6: 29382184 \mathrm{G}>\mathrm{A}$ & $\mathrm{G} / \mathrm{G}$ & 0.81 & G & 0.90 \\
\hline & & $\mathrm{G} / \mathrm{A}$ & 0.19 & A & 0.10 \\
\hline
\end{tabular}


Table 4. Least square means of litter traits in association with the observed genotypes

\begin{tabular}{|c|c|c|c|c|}
\hline Gene & SNP/Genotype & $\mathrm{n}=$ & LS & $\mathrm{BW}(\mathrm{Kg})$ \\
\hline \multirow[t]{17}{*}{$\overline{G D F 9 \text { (NC_019462.1) }}$} & 5: 41843258G $>$ A (G1) & & & \\
\hline & $\mathrm{A} / \mathrm{A}$ & 2 & 1.00 & 3.56 \\
\hline & $\mathrm{A} / \mathrm{G}$ & 31 & 1.17 & 3.62 \\
\hline & $\mathrm{G} / \mathrm{G}$ & 82 & 1.16 & 3.88 \\
\hline & SEM & & 0.18 & 0.33 \\
\hline & $P$ value & & 0.71 & 0.38 \\
\hline & $5: 41841675 A>G(G 4)$ & & & \\
\hline & $\mathrm{A} / \mathrm{A}$ & 4 & 1.00 & 3.62 \\
\hline & $\mathrm{A} / \mathrm{G}$ & 33 & 1.16 & 3.67 \\
\hline & $\mathrm{G} / \mathrm{G}$ & 78 & 1.18 & 3.87 \\
\hline & SEM & & 0.12 & 0.22 \\
\hline & $P$ value & & 0.42 & 0.65 \\
\hline & $5: 41840985 C>T(G U)$ & & & \\
\hline & $\mathrm{C} / \mathrm{C}$ & 110 & 1.16 & 3.79 \\
\hline & $\mathrm{C} / \mathrm{T}$ & 5 & 1.17 & 4.04 \\
\hline & SEM & & 0.13 & 0.23 \\
\hline & $P$ value & & 0.78 & 0.37 \\
\hline \multirow[t]{17}{*}{$B M P R 1 B\left(N C \_019463.1\right)$} & $6: 29382340 G>A$ & & & \\
\hline & $\mathrm{G} / \mathrm{G}$ & 84 & 1.17 & 3.74 \\
\hline & $\mathrm{G} / \mathrm{A}$ & 30 & 1.14 & 3.95 \\
\hline & $\mathrm{A} / \mathrm{A}$ & 1 & 1.00 & 4.36 \\
\hline & SEM & & 0.16 & 0.30 \\
\hline & $P$ value & & 0.81 & 0.23 \\
\hline & 6: $29382337 G>A$ & & & \\
\hline & $\mathrm{G} / \mathrm{G}$ & 53 & $1.14 \mathrm{~b}$ & 3.82 \\
\hline & $\mathrm{G} / \mathrm{A}$ & 49 & $1.12 \mathrm{~b}$ & 3.80 \\
\hline & $\mathrm{A} / \mathrm{A}$ & 13 & $1.41 \mathrm{a}$ & 3.76 \\
\hline & SEM & & 0.09 & 0.18 \\
\hline & $P$ value & & 0.04 & 0.57 \\
\hline & $6: 29382184 G>A$ & & & \\
\hline & $\mathrm{G} / \mathrm{G}$ & 93 & $1.20 \mathrm{a}$ & 3.82 \\
\hline & $\mathrm{G} / \mathrm{A}$ & 22 & $1.02 \mathrm{~b}$ & 3.74 \\
\hline & SEM & & 0.05 & 0.13 \\
\hline & $P$ value & & 0.02 & 0.72 \\
\hline
\end{tabular}

$\mathrm{n}=$ number of ewes at each genotype; LS: litter size; BW: lambs' birth weight; SEM: standard error of the mean; $a, b$ : the means with the same letter in each part of each column were not significantly different in Duncan's test at error level of 0.05 .

\section{Discussion}

The search for polymorphisms in four known major genes affecting prolificacy in the 115 Iranian Mehraban ewes resulted in detection of a total number of 10 SNP in only two genes namely GDF9 and BMPRIB. In GDF9, we detected six already de- 
scribed SNPs, firstly identified by Hanrahan et al. (2004) and a new one in the 3'UTR of the gene. In this specific gene, we focused particularly on G1 and G4 inducing non-conservative amino-acid substitutions (R87H and E241K) that could possibly affect the GDF9 biological activity. Notably, most of the heterozygous animals at G1 were also heterozygous at the G4 position indicating a probable local haplotype G1-G4 as attested by the high LD levels between the two SNPs. The existence of such simultaneous/dual mutation (G1 and G4) has also been reported in Afshari and Shal sheep (Eghbalsaied et al., 2014). Notably, the five animals carrying the specific haplotype were also the only carriers of the new GU SNP in the 3'UTR part of the GDF9 gene at position g.41840985C > T (NC_019462.1). The G1 polymorphism has been widely reported in all Iranian native breeds such as Mehraban (Abdoli et al., 2013), Baluchi (Moradband et al., 2011), Lori (Zamani et al., 2015 a), Afshari and Shal (Eghbalsaied et al., 2014), and Moghani and Ghezel sheep (Barzegari et al., 2010). According to Hanrahan et al. (2004), G1 has never been associated with prolificacy in the Cambridge and Belclare breeds. Nevertheless, some studies have reported the significant association of G1 with prolificacy in other sheep breeds (Barzegari et al., 2010; Javanmard et al., 2011; Moradband et al., 2011; Eghbalsaied et al., 2014; Zamani et al., 2015 a). Particularly, Paz et al. (2015), described G1 as the $\mathrm{Fec} \mathrm{G}^{l}$ mutation leading to increased LS in heterozygous animals (1.56) compared to the wild type genotype (1.25) in Chilean local sheep breeds. In contrast to the Paz et al. (2015) study, no significant association was detected between the G1 alleles and LS records in the Mehraban sheep. With regard to the G4 mutation, no significant association was evidenced with twin births in Greek sheep (Liandris et al., 2012) or Iranian native sheep breeds including Afshari, Ghezel, Lori-Bakhtyari, and Shal prolific sheep (Eghbalsaied et al., 2017). Accordingly, no significant effect of G4 on the LS and BW could be detected in Mehraban sheep.

Finally, the GDF9 sequencing of 16 ewes with extreme phenotypes did not highlight the already known prolific alleles at the $\mathrm{Fec} G$ locus, G7/Fec $G^{W N S}$, G8/Fec $G^{H}$, $F e c G^{E}, F e c G^{T}$ or Fec $G^{V}$ (Hanrahan et al., 2004; Nicol et al., 2009; Silva et al., 2011; Vage et al., 2013; Souza et al., 2014).

At the FecX locus, we showed that the BMP15 gene was not polymorphic in the studied prolific and non-prolific Mehraban ewes. However, Zamani et al. (2015 b) identified one silent polymorphism in the exon 2 of the BMP15 gene associated with an increase in the prolificacy of Mehraban and Lori sheep. Additionally, in the same two Iranian breeds, a new polymorphism in exon 1 of the BMP15 gene was identified inducing amino acid change $(\mathrm{E} 41 \mathrm{~K})$ but without any association with the reproductive traits (Nadri et al., 2016). In the present study, we did not sequence the entire BMP15 gene for all animals. Maybe these two polymorphisms are also segregating in the Mehraban population we have studied, but without any effect on prolificacy since they were absent from our highest prolific ewes sequenced for BMP15.

In a second step, we searched for the presence of the $F e c L^{L}$ prolific mutation on the chromosome 11 in the fourth known major locus controlling prolificacy in sheep (Drouilhet et al., 2013). The FecL $L^{L}$ mutation is not a loss-of-function mutation altering the protein sequence and is a regulatory mutation affecting the ovarian expres- 
sion of the B4GALNT2 gene (Drouilhet et al., 2013). Also here, the use of the KASP approach of the SNP OAR11:36938224T $>$ A (NC_019468.1) resulted in no detection of any carriers of the $F e c L^{L}$ mutation in Mehraban sheep.

Finally, we searched for polymorphisms lying in the same exon as the prolific $F e c B^{B}$ mutation in the $B M P R 1 B$ gene. The $F e c B$ mutation was initially discovered in the prolific Booroola strain of Merino sheep. It was identified as a SNP A $>\mathrm{G}$ in the BMPR1B exon 7 at position g.29382188 (NC_019463.1) on the chromosome 6 (Mulsant et al., 2001; Wilson et al., 2001). Apart from Merino sheep, FecB ${ }^{B}$ segregated in numerous breeds such as Garole (Davis et al., 2002; Polley et al., 2009), Javanese (Bradford et al., 1986), Small Tailed Han (Liu et al., 2003; Wang et al., 2003; Yan et al., 2005), Hu (Wang et al., 2003), Duo Lang (Zhong et al., 2005), Kendrapada (Kumar et al., 2008), and Cele black (Shi et al., 2010) sheep. Interestingly, the $F e c B^{B}$ mutation is also present in the Kalehkoohi Iranian local breed with a significant positive effect on the LS (Mahdavi et al., 2014). Moreover, Abdoli et al. (2013) have discovered in the vicinity of $F e c B^{B}$ a new polymorphism g.29382185 C > A altering the protein sequence (p.T250K). This SNP has also been shown to be associated with prolificacy of Mehraban sheep (Abdoli et al., 2013). In our study, these two known variants (g.29382188 A>G and g.29382185 C>A) were not evidenced. However, we have found three novel SNPs in the exon 7 of BMPR1B. One of them (g.29382340 G>A) was not associated with litter traits, but the other two were significantly associated with the variation of LS. Interestingly, the minor alleles of these two SNP have opposite effects on LS, g.29382337A increased LS by +0.3 at the homozygous state while g.29382184A decreased LS by -0.2 lambs at the heterozygous state. These SNPs are silent at the level of the BMPR1B protein sequence (Table 2) and they are not considered as potential causal mutation controlling sheep prolificacy. However, they could be in strong LD with a new causal mutation in the BMPRIB locus which remains to be discovered.

In conclusion, based on LS records and selection of high prolific Mehraban ewes with repeated lambing of twins, we evidenced genetic polymorphisms at two major loci already known to control ovulation rate and prolificacy in sheep GDF9 and $B M P R 1 B$. At the GDF9 locus, none of the detected polymorphisms was associated with the LS variation in Mehraban ewes. At the BMPR1B locus, we have evidenced two novel SNPs in exon 7 with possible effect on LS. These two SNPs may provide valuable genetic markers for increasing LS in the Mehraban sheep while confirming the role of the $B M P R 1 B$ locus in controlling sheep prolificacy. Nevertheless, further studies using a greater number of individuals are warranted. Among them a GWAS (genome-wide association study) approach is expected to be a valuable method for detecting genetic markers of prolificacy in the Mehraban sheep.

\section{Acknowledgments}

R.T. has greatly appreciated the hosting from Toulouse INRA research center in France for the technical assistance, the provision of reagents and equipment and for the sequencing of DNA samples. Authors wanted to thank Mr. Rasol Yazdi, Miss Zhila Rajabi and Mr. Sadreddin Anvari from the Bu-Ali Sina University of Hamedan, Iran, for blood sampling and prolificacy records. 


\section{Conflict of interest statement}

The authors declare that there is no conflict of interests regarding the publication of this article.

\section{References}

A bdoli R., Zamani P., Deljou A., Rezvan H. (2013). Association of BMPR-1B and GDF9 genes polymorphisms and secondary protein structure changes with reproduction traits in Mehraban ewes. Gene, 524: 296-303.

Abdoli R., Zamani P., Mirhoseini S.Z., Ghavi Hos sein-Zadeh N., Nadri S. (2016). A review on prolificacy genes in sheep. Reprod. Domest. Anim., 51: 631-637.

A tashi H., Izadifard J., Z am ir i M.J., Akhlaghi A. (2013). Investigation in early growth traits, litter size, and lamb survival in two Iranian fat-tailed sheep breeds. Trop. Anim. Health. Prod., 45: 1051-1054.

Bahrami A., Behzadi S.H., Miraei-Ashtiani S.R., Roh S.G., Katoh K. (2013). Genetic polymorphisms and protein structures in growth hormone, growth hormone receptor, ghrelin, insulin-like growth factor 1 and leptin in Mehraban sheep. Gene, 527: 397-404.

Barzegari A., A tashpaz S., Ghabili K., Nemati Z., RustaeiM., Azarbaijani R. (2010). Polymorphisms in GDF9 and BMP15 associated with fertility and ovulation rate in Moghani and Ghezel sheep in Iran. Reprod. Domest. Anim., 45: 666-669.

Bradford G.E., Quirke J.F., S it orus P., In ounu I., Tiesnamurti B., Bell F.L., Flet ch e r I.C., Tor ell D.T. (1986). Reproduction in Javanese sheep: evidence for a gene with large effect on ovulation rate and LS. J. Anim. Sci., 63: 418-431.

D a v i s G.H. (2005). Major genes affecting ovulation rate in sheep. Genet. Sel. Evol., 37: 11-23.

Davi is G.H., Gallow a y.M., Ros s I.K., Gre gan S.M., Ward J., Ni mbkar B.V., Ghal sasi P.M., Nimbkar C., Gray G.D., Subandriyo, Inounu I., Tiesnamurti B., Martyniuk E., Eythorsdott ir E., Muls ant P., Lecerf F., Hanrahan J.P., Bradford G.E., Wils on T. (2002). DNA tests in prolific sheep from eight countries provide new evidence on origin of the Booroola $(F e c B)$ mutation. Biol. Reprod., 66: 1869-1874.

Drou il he t L., L e c e r f F., B o d in L., F a bre S., M u 1 s a n t P. (2009). Fine mapping of the FecL locus influencing prolificacy in Lacaune sheep. Anim. Genet., 40: 804-812.

Drouilhet L., Mansanet C., S arry J., Tabet K., B ardou P., Woloszyn F., Lluch J., Harichaux G., Viguié C., Monniaux D., Bodin L., Mulsant P., Fabre S. (2013). The highly prolific phenotype of Lacaune sheep is associated with an ectopic expression of the B4GALNT2 gene within the ovary. PLoS Genet, 9: e1003809.

Eghbalsaied S., Amini H., Shahmoradi S., Farahi M. (2014). Simultaneous presence of G1 and G4 mutations in growth differentiation factor 9 gene of Iranian sheep. Iran. J. Appl. Anim. Sci., 4 : 781-785.

Eghbalsaied S., RashidiKhorasgani F., Amini H.R., Farahi M., Davari M., Pirali A., Pourali S., Vatankhah M., Rostami M., A tashi H. (2017). Variant GDF9 mRNA is likely not the main cause of larger litter size in Iranian Lori-Bakhtyari, Shal, Ghezel, and Afshari sheep breeds. Arch. Anim. Breed., 60: 119-129.

Galloway S.M., McNatty K.P., Cambridge L.M., Laitinen M.P., Juengel J.L., Jok ir ant a T.S., M c Laren R.J., Lu iro K., D odds K.G., M on tg o mery G.W., B e a t ti e A.E., D a vis G.H., Ritv o s O. (2000). Mutations in an oocyte-derived growth factor gene (BMP15) cause increased ovulation rate and infertility in a dosage-sensitive manner. Nat. Genet., 25: 279-283.

H anrahan J.P., Gregan S.M., Muls ant P., Mulle n M., D a v is G.H., Powell R., Gal10 w a y S.M. (2004). Mutations in the genes for oocyte-derived growth factors GDF9 and BMP15 are associated with both increased ovulation rate and sterility in Cambridge and Belclare sheep (Ovis aries). Biol. Reprod., 70: 900-909.

Janssens S., Vandepitte W., B odin L. (2004). Genetic parameters for LS in sheep: natural versus hormone-induced oestrus. Genet. Sel. Evol., 36: 543-562. 
Javanmard A., A zadzadeh N., Esmailizadeh A.K. (2011). Mutations in bone morphogenetic protein 15 and growth differentiation factor 9 genes are associated with increased LS in fattailed sheep breeds. Vet. Res. Commun., 35: 157-167.

K u mar S., M is hr a A.K., Kolt e A.P., D a s h S.K., K ar i m S.A. (2008). Screening for Booroola $(F e c B)$ and Galway $\left(F e c X^{G}\right)$ mutations in Indian sheep. Small Rumin. Res., 80: 57-61.

Liandris E., Kominakis A., Andreadou M., Kapeoldassi K., Chadio S., Tsiligia n n i T.H., Gazouli M., I k o n o mo poulos I. (2012). Associations between single nucleotide polymorphisms of GDF9 and BMP15 genes and litter size in two dairy sheep breeds of Greece. Small Rumin. Res., 107: 16-21.

Li i S.F., J i a n g Y.L., D u L.X. (2003). Studies of BMPRIB and BMP15 as candidate genes for fecundity in little tailed han sheep. Yi ChuanXueBao. Acta Genet. Sin., 30: 755-760.

M a h d avi M., N a n e karan i S., Hos s e in i S.D. (2014). Mutation in BMPR-IB gene is associated with LS in Iranian Kalehkoohi sheep. Anim. Reprod. Sci., 147: 93-98.

M o n t g o m e r y G.W., S i s e J.A. (1990). Extraction of DNA from sheep white blood cells. New. Zeal. J. Agr. Res., 33: 437-441.

Moradband F., Rahimi G., Gholizadeh M., (2011). Association of polymorphism in fecundity genes of GDF9, BMP15 and BMPR-1B with LS in Iranian Baluchi sheep. Asian Austral. J. Anim. Sci., 24: 1179-1183.

Mulsant P., Lecerf F., Fabre S., S chibler L., Monget P., Lanneluc I., P isselet C., Riquet J., Mon-niaux D., Callebaut I., Cribiu E., Thimonieri J., Teyssieri J., Bodin L., Cognie Y., Chitour N., Els en J.M. (2001). Mutation in bone morphogenetic protein receptor-IB is associated with increased ovulation rate in Booroola Merino ewes. Proc. Natl. Acad. Sci. U S A., 98: 5104-5109.

$\mathrm{Nadri}$ S., Z a mani P., A hmadi A. (2016). Novel mutation in exon 1 of the BMP15 gene and its association with reproduction traits in sheep. Anim. Biotechnol., 27: 256-261.

Nicol L., Bishop S.C., Pong-Wong R., Bendixen C., Holm L-E., Rhind S.M., Mc- N e il1 y S.A. (2009). Homozygosity for a single base-pair mutation in the oocyte specific GDF9 gene results in sterility in Thoka sheep. Reproduction, 138: 921-933.

N o t t e r D.R. (2008). Genetic aspects of reproduction in sheep. Reprod. Domestic. Anim., 43: 122-128.

Paz E., Quiñones J., Bravo S., Montaldo H.H., S e púlveda N. (2015). Genotyping of BMPR1B, BMP15 and GDF9 genes in Chilean sheep breeds and association with prolificacy. Anim. Genet., 46: 98-99.

Persani L., Rossetti R., Di Pasquale E., Cacciatore C., Fabre S. (2014). The fundamental role of bone morphogenetic protein 15 in ovarian function and its involvement in female fertility disorders. Hum. Reprod. Update., 20: 869-883.

Polley S., D e S., B a tabyal S., K a ushik R., Yadav P., A rora J.S., Chat to padhy ay S., P a n S., B rahma B., D at t a T.K., G o s w a m i S.L. (2009). Polymorphism of fecundity genes (BMPR1B, BMP15 and GDF9) in the Indian prolific Black Bengal goat. Small Rumin. Res., 85: $122-129$.

Ricordeau G., Thimonier J., Poivey J.P., Driancourt M.A., Hochereau-De- Reviers M.T., Tch a mitc h i a L L. (1990). I.N.R.A. research on the Romanov sheep breed in France: A review. Livest. Prod. Sci., 24: 305-332.

SAS Institute (2004). Users guide version 9.1: Statistics SAS Institute, Cary, NC.

Shi H., Jie B., Zhig ang N., Munire sha L.F., B in J. (2010). Study on candidate gene for fecundity traits in Xingiiang Cele black sheep. Afr. J. Biotechnol., 9: 8498-8505.

Silva B.D., Castro E.A., S o uza C.J., Pa iva S.R., S artori R., Franco M.M., A zeve d o H.C., Silva T.A.S.N., Vi e ir a A.M.C., $\mathrm{Nev}$ e s J.P., M e lo E.O. (2011). A new polymorphism in the growth and differentiation factor $9(G D F 9)$ gene is associated with increased ovulation rate and prolificacy in homozygous sheep. Anim. Genet., 42: 89-92.

$\mathrm{S}$ ou za C.J., Mc Neilly A.S., B e n a vides M.V., Melo E.O., M or a e s J.C.F. (2014). Mutation in the protease cleavage site of GDF9 increases ovulation rate and LS in heterozygous ewes and causes infertility in homozygous ewes. Anim. Genet., 45: 732-739.

Vage D.I., Husdal M., Matthew P.K., Klemetsdal G., Boman I.A. (2013). A missense mutation in growth differentiation factor $9(G D F 9)$ is strongly associated with LS in sheep. BMC Genet., 14: 1 . 
Wang G.L., Ma o X.Z., D a v is G.H., Z ha o Z.S., Z hang L.J., Z eng Y.Q. (2003). DNA tests in Hu sheep and Han sheep (small tail) showed the existence of Booroola $(F e c B)$ mutation. J. Nanjing Agric. Univ., 26: 104-106.

Wil s on T., Wu X.Y., J u e n gel J.L., R o s s I.K., L u m s d e n J.M., L ord E.A., D o d d s K.G., Walling G.A., McEwan J.C., O' Connell A.R. (2001). Highly prolific Booroola sheep have a mutation in the intracellular kinase domain of bone morphogenetic protein IB receptor (ALK6) that is expressed in both oocytes and granulosa cells. Biol. Reprod., 64: 1225-1235.

Yan Y.D., Chu M.X., Zeng Y.Q., Fang L., Ye S.C., Wang L.M., Guo Q.K., Han D.Q., Zhang Z.X., Wang X.J., Zhang X.Z. (2005). Study on bone morphogenetic protein receptor IB as a candidate gene for prolificacy in Small Tailed Han sheep and Hu sheep (in Chinese). J. Agric. Biotechnol., 13: 66-71.

Yeh F.C., Yang R., B o y le T. (1999). POPGENE. Version 1.31. Microsoft window-based freeware for population genetic analysis, University of Alberta. Edmonton, AB, Canada.

Z a mani P., Mohammadi H. (2008). Comparison of different models for estimation of genetic parameters of early growth traits in the Mehraban sheep. J. Anim. Breed. Genet., 125: 29-34.

Zamani P., Abdoli R., Deljou A., Rezvan H. (2015 a). Polymorphism and bioinformatics analysis of growth differentiation factor 9 gene in Lori sheep. Ann. Anim. Sci., 15: 337-348.

Zamani P., Nadri S., Saffaripour R., Ahmadi A., Dashti F., Abdoli R. (2015 b). A new mutation in exon 2 of the bone morphogenetic protein 15 gene is associated with increase in prolificacy of Mehraban and Lori sheep. Trop. Anim. Health. Prod., 47: 855-860.

Zhong F.G., Wang X.H., Liu S.R., Li H., Chen X.J., Yin J.L., Ni J.H. (2005). Study on the polymorphism of $B M P R$-IB gene associated with litter size in small-tailed Han sheep and Xinjiang Duolang sheep (in Chinese). China Herbivor., 25: 15-16.

Received: 3 VIII 2017

Accepted: 12 II 2018 